\title{
$N y-1$ and $N y-2$ genes conferring hypersensitive response to potato virus Y (PVY) in cultivated potatoes: mapping and marker-assisted selection validation for PVY resistance in potato breeding
}

\author{
Katarzyna Szajko • Danuta Strzelczyk-Żyta • \\ Waldemar Marczewski
}

Received: 6 September 2013 / Accepted: 10 January 2014/Published online: 23 January 2014

(C) The Author(s) 2014. This article is published with open access at Springerlink.com

\begin{abstract}
Potato virus Y (PVY) is one of the most important viruses affecting potato (Solanum tuberosum) production. In this study, a novel hypersensitive response (HR) gene, $\mathrm{Ny}$-2, conferring resistance to PVY was mapped on potato chromosome XI in cultivar Romula. In cultivars Albatros and Sekwana, the $N y-1$ gene was mapped on chromosome IX. In cv. Romula, the local lesions appeared in leaves inoculated with the PVY ${ }^{\mathrm{N}-\mathrm{Wi}}$ isolate at 20 and $28^{\circ} \mathrm{C}$; PVY systemic infections were only occasionally observed at the higher temperature. In cvs. Albatros and Sekwana, expression of the necrotic reaction to virus infection was temperature-dependent. $\mathrm{PVY}^{\mathrm{N}-\mathrm{Wi}}$ was localized at $20{ }^{\circ} \mathrm{C}$; at $28{ }^{\circ} \mathrm{C}$, the systemic, symptomless infection was observed. We developed the B11.6 1600 marker co-segregating with $N y-2$ and the S1d11 marker specific for the $N y-1$ gene. Fifty potato cultivars were tested with markers B11.6 and S1d11 and marker SC895 linked to the $N y-1$ gene in cv. Rywal. These results indicated the utility of these markers for marker-assisted selection of HR-like PVY resistance in potato breeding programs.
\end{abstract}

K. Szajko · D. Strzelczyk-Żyta · W. Marczewski ( $\square)$ Plant Breeding and Acclimatization Institute, National Research Institute, Platanowa 19, 05-831 Młochów, Poland

e-mail: w.marczewski@ihar.edu.pl
Keywords Potato cultivars · PVY .

Hypersensitivity $\cdot$ Mapping $\cdot$ Marker-assisted selection

Potato virus $\mathrm{Y}$ (PVY) is the most harmful virus infecting potato crops (Valkonen 2007). In potato cultivars, $R y$ genes confer extreme resistance (ER) to all PVY strains. Plants expressing ER typically remain symptomless, with extremely low viral accumulation in inoculated leaves (Valkonen et al. 1996; Hämäläinen et al. 1998). Three genes that confer ER resistance were identified in potato: the $R y_{\text {sto }}$ gene (also designated as $R y-f_{\text {sto }}$ ) derived from $S$. stoloniferum on potato chromosome XII (Flis et al. 2005; Song et al. 2005); the $R y_{a d g}$ gene from $S$. tuberosum ssp. andigena on chromosome XI (Hämäläinen et al. 1997), and $R y_{c h c}$ from $S$. chacoense on chromosome IX (Sato et al. 2006). The hypersensitive response (HR) is another potato defense mechanism against PVY (Valkonen et al. 1996). The typical HR involves effective pathogen restriction in infected cells, which is associated with necrotic lesion generation at infection sites (Kang et al. 2005). Studies have shown that HR is responsible for limiting pathogen spread, which has the potential to result in systemic necrosis development (Valkonen et al. 1996). Rywal is the first potato cultivar in which temperature-dependent $\mathrm{HR}$ expression against $\mathrm{PVY}^{\mathrm{O}}$ and $\mathrm{PVY}^{\mathrm{N}}$ strains was detected. The Ny-1 gene was mapped on potato chromosome IX (Szajko et al. 2008). Here we report mapping of HR- 
like genes conferring resistance to PVY in potato cultivars Albatros, Sekwana, and Romula, and the development of PCR markers useful for markerassisted selection in potato breeding programs.

Three potato cultivars, Albatros, Romula and Sekwana, were evaluated for resistance to the isolate $\mathrm{PVY}^{\mathrm{N}-\mathrm{Wi}}$ (accession number Z70238). The $\mathrm{PVY}^{\mathrm{N}-\mathrm{Wi}}$ status was verified using the protocol reported by Lorenzen et al. (2006). Potato plants were grown for 2 weeks under greenhouse conditions, and transferred 1 week prior to infection experiments to growth chambers under controlled environmental conditions (20 or $28{ }^{\circ} \mathrm{C}, 16 \mathrm{~h}$ light at $100 \mathrm{~mol} / \mathrm{s} / \mathrm{m}^{2}, 8 \mathrm{~h}$ dark). For each cultivar, six plants were mechanically inoculated with a sap extracted from the tobacco plants that were infected with $\mathrm{PVY}^{\mathrm{N}-\mathrm{Wi}}$. Inoculated potato plants were divided into two groups; one group was incubated at $20^{\circ} \mathrm{C}$, the other at $28{ }^{\circ} \mathrm{C}$. Watertreated detached leaves and plants were used as negative controls. Samsun tobacco plants inoculated with $\mathrm{PVY}^{\mathrm{N}-\mathrm{Wi}}$ were used as positive controls. Hypersensitivity was visualized after 4-6 days. Nine days following inoculation, $1 \mathrm{~g}$ of inoculated and noninoculated upper leaf samples from each of the plants was collected to detect the virus by RT-PCR, which was performed as described by Szajko et al. (2008) with minor modifications. In addition, ELISA tests were performed on inoculated and upper leaves 3 weeks post-inoculation at $20{ }^{\circ} \mathrm{C}$. PVY monoclonal cocktail Bioreba AG kit (Reinach, Switzerland) was used. Experiments were repeated three times with similar results.

At $20{ }^{\circ} \mathrm{C}$, cvs. Albatros and Sekwana exhibited a hypersensitive response to $\mathrm{PVY}^{\mathrm{N}-\mathrm{Wi}}$ infection in inoculated leaves. The virus was not detected in the upper, non-inoculated leaves. At $28^{\circ} \mathrm{C}$, systemic symptomless infections were observed. In cv. Romula, the local necrotic lesions appeared at 20 and $28{ }^{\circ} \mathrm{C}$. Occasionally, HR failed to restrict PVY progression to upper, non-inoculated leaves of $\mathrm{cv}$. Romula grown at $28^{\circ} \mathrm{C}$. Albatros (A) and Sekwana (Se) were crossed with the PVY-susceptible Dutch cultivar Accent (Ac) to obtain mapping populations $\mathrm{A} \times \mathrm{Ac}$ and $\mathrm{Se} \times \mathrm{Ac}$ with 42 and $58 \mathrm{~F} 1$ individuals, respectively. A segregating $\mathrm{F} 1$ population $\mathrm{R} \times \mathrm{F}$ was established consisting of 52 individuals derived from a cross between cv. Romula (R) and Polish cultivar Felka (F). Two tuber-derived plants per each F1 individual clone representing populations $\mathrm{A} \times \mathrm{Ac}, \mathrm{Se} \times \mathrm{Ac}$, and
$\mathrm{R} \times \mathrm{F}$ were screened for $\mathrm{HR}$ to $\mathrm{PVY}^{\mathrm{N}-\mathrm{Wi}}$ infection at $20{ }^{\circ} \mathrm{C}$. Plants which developed necrotic symptoms 6 days post-inoculation were classified as resistant. The following ratios of resistant to susceptible plants were detected: $\mathrm{A} \times \mathrm{Ac}-24: 18, \mathrm{Se} \times \mathrm{Ac}-30: 28$, and $\mathrm{R} \times \mathrm{F}-24: 28$. The segregation ratios of $1: 1$ $\left(\chi^{2}=0.85, P=0.35 ; \chi^{2}=0.07, P=0.79 ;\right.$ and $\chi^{2}=0.31, P=0.58$, respectively) confirmed the presence of single, dominant genes for HR to PVY in simplex states in all three resistant cultivars.

Five markers, S1d11, GP129, U38666, ShkB, and $\mathrm{N} 127$, were amplified in $20 \mu \mathrm{l}$ of $20 \mathrm{mM}$ Tris-HCl pH $8.4,50 \mathrm{mM} \mathrm{KCl}, 1.5 \mathrm{mM} \mathrm{MgCl} 2,0.1 \mathrm{mM}$ of each $\mathrm{dNTP}, 0.2 \mu \mathrm{M}$ of each primer, $1 \mathrm{U}$ Taq DNA polymerase (Invitrogen, Carlsbad, CA, USA), and $30 \mathrm{ng}$ genomic DNA. $\mathrm{MgCl}_{2}$ concentration was increased to $3 \mathrm{mM}$ for amplification of three markers: U276927, TG186, and TG591. In addition, $1 \mathrm{U}$ of DreamTaq ${ }^{\mathrm{TM}}$ DNA polymerase and $1 \times$ buffer containing $2 \mathrm{mM}$ $\mathrm{MgCl}_{2}$ (Fermentas, Vilnius, Lithuania) were used for marker B11.6. The following PCR parameters were employed: initial denaturation at $94{ }^{\circ} \mathrm{C}$ for $60 \mathrm{~s}$ followed by 40 cycles of denaturation at $93{ }^{\circ} \mathrm{C}$ for $25 \mathrm{~s}$, annealing at $54-62{ }^{\circ} \mathrm{C}$ for $35 \mathrm{~s}$ (Table 1), and extension at $72{ }^{\circ} \mathrm{C}$ for $90 \mathrm{~s}$, with a final extension at $72{ }^{\circ} \mathrm{C}$ for $5 \mathrm{~min}$. The sequence characterized amplified region (SCAR) marker SC895 (NCBI GenBank accession EF555209) was amplified as described by Szajko et al. (2008). The At3g24050 (SGN U270244) marker was co-amplified with SC895 as an internal PCR control. At3g24050 primers comprised forward: 5'-CCTCTGGGGCCGAAAACACT- $3^{\prime}$ and reverse: 5'-TCCATCACGAGCGAACACCAC- $3^{\prime}$.

Nine cleaved amplified polymorphic sequence (CAPS) markers were employed for mapping (Table 1). Four markers, TG591, S1d11, U38666, and TG186, exhibited utility in mapping the HR gene on potato chromosome IX in cv. Albatros. TG591 and S1d11, as well as GP129 and U276927, confirmed the presence of the HR gene in the same region of chromosome IX in cv. Sekwana (Fig. 1). The infection symptoms and the map positions of the PVY resistance loci in these cultivars were similar to those described for the $N y-1$ gene in cv. Rywal (Szajko et al. 2008). The HR genes in cvs. Albatros and Sekwana were therefore designated $N y-1$. However, further molecular studies are necessary to determine whether $N y-1$ in cvs. Albatros, Rywal, and Sekwana reside at the same resistance locus, or whether these cultivars 


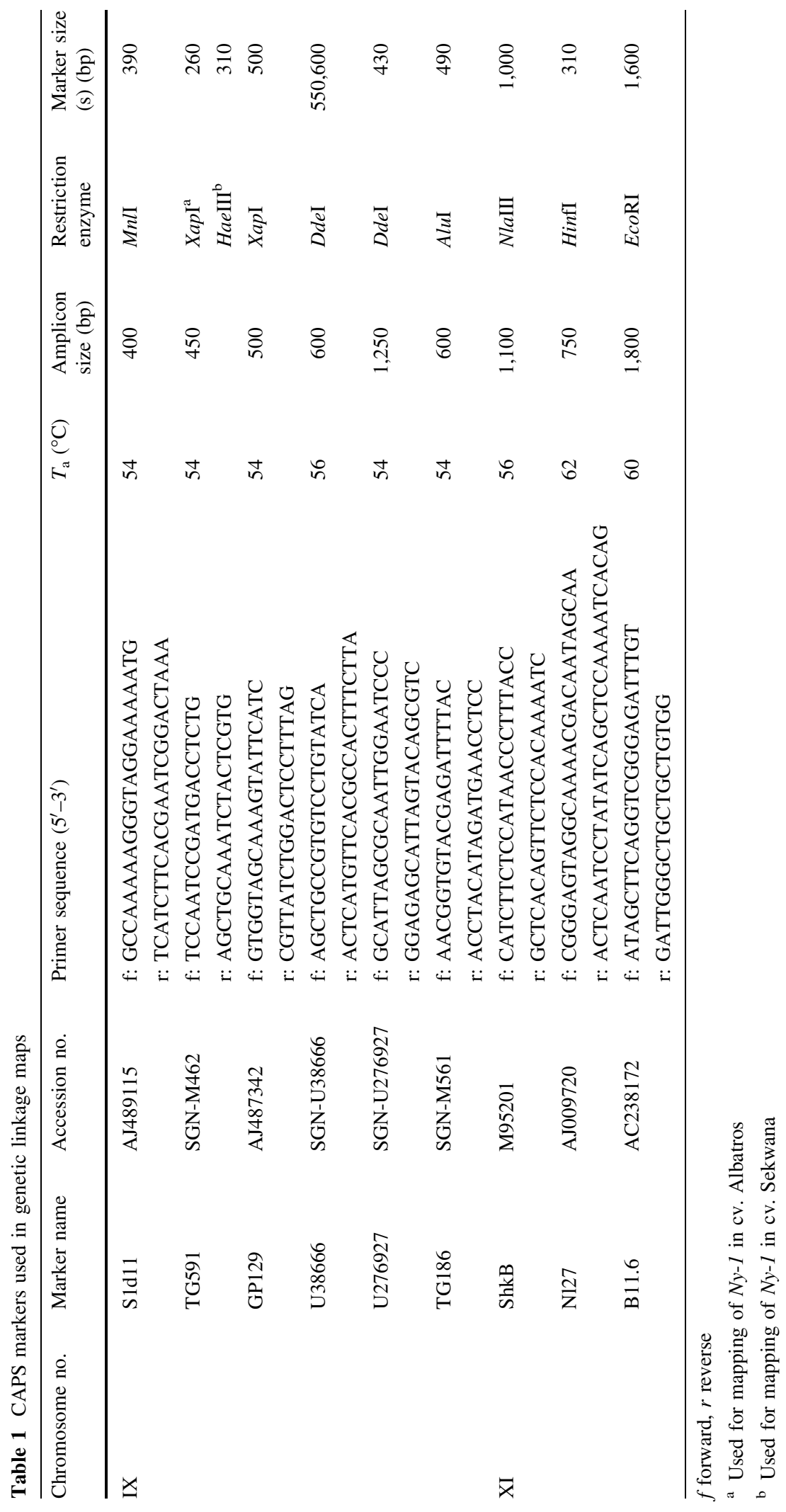



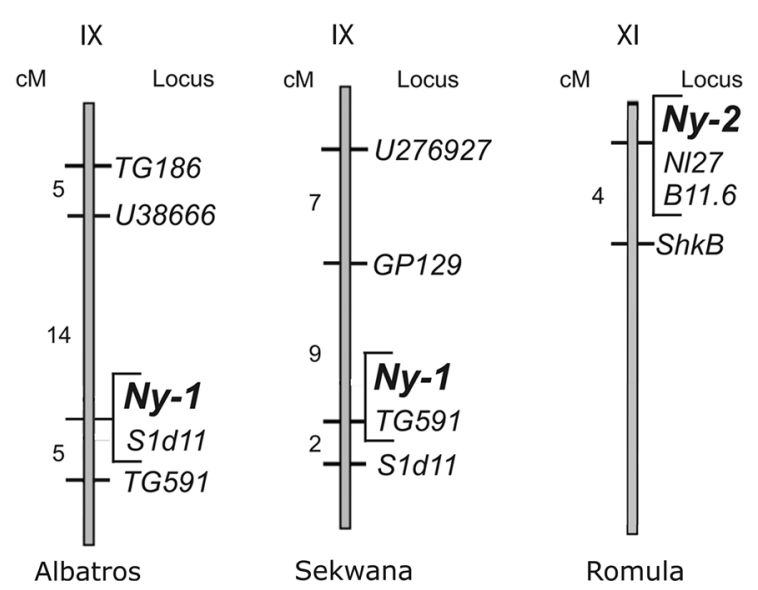

Fig. 1 Positions of the loci $N y-1$ on chromosome IX in cvs. Albatros and Sekwana and $N y-2$ on chromosome XI cv. Romula. Genetic distances in $\mathrm{cM}$ are shown on the left. The map distances were calculated from recombination frequencies between DNA markers and resistance loci

carry PVY resistance genes located at different loci on potato chromosome IX. Three DNA markers, N127, ShkB, and B11.6, were useful for mapping the HR-like gene $N y$-2 for PVY resistance on chromosome XI in cv. Romula (Fig. 1), in a resistance hotspot containing genes for qualitative and quantitative resistance to pathogens. The $R y_{\text {adg }}$ gene for ER to PVY has been previously mapped to this chromosome region (Hämäläinen et al. 1997). However, the diagnostic marker RYSC3 for the $R y_{a d g}$ gene (Kasai et al. 2000) was not amplified in cv. Romula.

Fifty potato cultivars (Table 2), bred in Poland, Germany, and The Netherlands, were tested for the presence of the SCAR marker SC895 and two CAPS markers, S1d11 and B11.6. Markers TG591 and N127 were not informative. Pedigree information (available for most cvs. at http://www.plantbreeding.wur.nl/ potatopedigree/) shows that these cultivars represent various potato genetic backgrounds. They were classified into three groups: ER (extreme resistance to PVY), HR (hypersensitive), and S (susceptible). DNA of seven ER German cultivars (Assia, Barbara, Esta, Heidrun, Pirola, Ute, and Wega) were received from the Max Planck Institute for Plant Breeding Research, courtesy of Dr. C. Gebhardt. The remaining 43 were classified for PVY resistance at Młochów as previously described (Flis et al. 2005; Witek et al. 2006; Szajko et al. 2008; Valkonen et al. 2008). SC895, S1d11, and B11.6 were not detected in the sixteen cvs.
Table 2 Distribution of markers SC895, S1d11, and B11.6 in potato cultivars

\begin{tabular}{|c|c|c|c|c|}
\hline \multirow{2}{*}{$\begin{array}{l}\text { Response } \\
\text { to PVY }\end{array}$} & \multirow[t]{2}{*}{ Potato cultivar } & \multicolumn{3}{|c|}{ Presence of markers } \\
\hline & & SC895 & S1d11 & B11.6 \\
\hline \multirow[t]{4}{*}{ HR } & Rywal & + & - & - \\
\hline & $\begin{array}{l}\text { Albatros, Koga, } \\
\text { Neptun, Niagara, } \\
\text { Sekwana }\end{array}$ & - & + & - \\
\hline & Korona, Romula & - & - & + \\
\hline & Mors, Syrena & - & - & - \\
\hline \multirow[t]{2}{*}{ ER } & $\begin{array}{l}\text { Gabi, Jasia, Maryna, } \\
\text { Santé, Ślęza, Sonda }\end{array}$ & - & - & + \\
\hline & $\begin{array}{l}\text { Ania, Assia, Baszta, } \\
\text { Beata, Barbara, } \\
\text { Danusia, Dunajec, } \\
\text { Esta, Fregata, } \\
\text { Heidrun, Hinga, } \\
\text { Kuba, Nimfy, Pirola, } \\
\text { Umiak, Ursus, Ute, } \\
\text { Wega }\end{array}$ & - & - & - \\
\hline S & $\begin{array}{l}\text { Accent, Balbina, } \\
\text { Delikat, Drop, Felka, } \\
\text { Grot, Karatop, } \\
\text { Karlena, Oda, Orłan, } \\
\text { Pirol, Tara, Tokaj, } \\
\text { Triada, Wawrzyn, } \\
\text { Wolfram }\end{array}$ & - & - & - \\
\hline
\end{tabular}

$H R$ hypersensitive response, $E R$ extreme resistance, $S$ susceptible, + presence of marker; - absence of marker

susceptible to PVY and eighteen cvs. that expressed ER to PVY. In cvs. Mors and Syrena, which were also negative for all three markers, recombination events or the presence of another source of HR against PVY might be possible. SC895 was specific only to $\mathrm{cv}$. Rywal. Therefore, this marker has potent utility for PVY resistance selection in progeny originated from the Rywal-derived source. The possibility that $N y-1$ and $N y-2$ genes are involved in resistance to PVY in the corresponding cvs. Koga, Neptun, Niagara, and Korona should be supported by additional genetic studies. Detection of the B11.6 marker in six cvs. from the ER group might be explained by epistatic expression of the Ry gene over $N y$ genes, where both types of PVY resistance genes are present in these cultivars, but the hypersensitive response is not induced. In diploid potato, this interaction type was exhibited between the PVY resistance genes $R y_{a d g}$ and $N y_{a d g}$ (Valkonen et al. 1994). 
In cultivated potato, a cross between a clone possessing two resistance alleles and a susceptible clone, or between two simplex resistant parents, resulted in a large percentage of resistant clones in F1 generations (Solomon-Blackburn and Mackay 1993). The PCR-based markers developed in this study might facilitate the production of PVY-resistant tetraploid potato clones with double HR gene doses, or the combination of HR and ER resistance factors, thereby improving breeding efficiency for PVY resistance in cultivated potato.

Acknowledgments We thank Professor M. Chrzanowska for help with selection of the cultivars for this study and Professor E. Zimnoch-Guzowska for helpful comments on the manuscript. The research was supported by The National Centre for Research and Development in Poland, Grant NR12 0002/06/ 2009.

Open Access This article is distributed under the terms of the Creative Commons Attribution License which permits any use, distribution, and reproduction in any medium, provided the original author(s) and the source are credited.

\section{References}

Flis B, Hennig J, Strzelczyk-Żyta D, Gebhardt C, Marczewski W (2005) The Ry- $f_{\text {sto }}$ gene from Solanum stoloniferum for extreme resistant to Potato virus $Y$ maps to potato chromosome XII and is diagnosed by PCR marker GP122 $2_{718}$ in PVY resistant potato cultivars. Mol Breed 15:95-101

Hämäläinen JH, Watanabe KN, Valkonen JPT, Arihara A, Plaisted RL, Pehu E, Miller L, Slack SA (1997) Mapping and marker-assisted selection for a gene for extreme resistance to potato virus Y. Theor Appl Genet 94:192-197

Hämäläinen JH, Sorri VA, Watanabe KN, Gebhardt C, Valkonen JPT (1998) Molecular examination of a chromosome region that controls resistance to potato $\mathrm{Y}$ and $\mathrm{A}$ potyviruses in potato. Theor Appl Genet 96:1036-1043

Kang B-Ch, Yeam I, Jahn MM (2005) Genetic of plant virus resistance. Ann Rev Phytopathol 43:581-621
Kasai K, Morikawa Y, Sorri VA, Valkonen JPT, Gebhardt C, Watanabe KN (2000) Development of SCAR markers to the PVY resistance gene $R y_{\text {adg }}$ based on a common feature of plant disease resistance genes. Genome 43:1-8

Lorenzen JH, Piche LM, Gudmestad NC, Meacham T, Shiel P (2006) A multiplex PCR assay to characterize Potato virus $Y$ isolates and identify strain mixtures. Plant Dis 90:935-940

Sato M, Nishikawa K, Komura K, Kosaka K (2006) Potato virus $Y$ resistance gene, $R y_{c h c}$, mapped to the distal end of potato chromosome 9. Euphytica 149:367-372

Solomon-Blackburn RM, MacKay GR (1993) Progeny testing resistance to potato virus $\mathrm{Y}$ : a comparison of susceptible potato cultivars for use in test-crosses with resistant parents. Potato Res 36:327-333

Song YS, Hepting L, Schweizer G, Hartl L, Wenzel G, Schwarzfischer A (2005) Mapping of extreme resistance to PVY $\left(R y_{s t o}\right)$ on chromosome XII using anther-culturederived primary dihaploid potato lines. Theor Appl Genet 111:879-887

Szajko K, Chrzanowska M, Witek K, Strzelczyk-Żyta D, Zagórska H, Gebhardt C, Hennig J, Marczewski W (2008) The novel gene $N y-1$ on potato chromosome IX confers hypersensitive resistance to Potato virus $Y$ and is an alternative to $R y$ genes in potato breeding for PVY resistance. Theor Appl Genet 116:297-303

Valkonen JPT (2007) Viruses: economical losses and biotechnological potential. In: Vreugdenhil D, Bradshaw J, Gebhardt C, Govers F, Taylor M, MacKerron D, Ross H (eds) Potato biology and biotechnology: advances and perspectives. Elsevier, Amsterdam, pp 619-641

Valkonen JPT, Slack SA, Plaisted RL, Watanabe KN (1994) Extreme resistance is epistatic to hypersensitive resistance to potato virus $\mathrm{Y}^{\mathrm{O}}$ in a Solanum tuberosum ssp. andigenaderived potato genotype. Plant Dis 78:1177-1180

Valkonen JPT, Jones RAC, Slack SA, Watanabe KN (1996) Resistance specificity to viruses in potato: standardization of nomenclature. Plant Breed 115:433-438

Valkonen JPT, Wiegmann K, Hämäläinen JH, Marczewski W, Watanabe KN (2008) Evidence for utility of the same PCRbased markers for selection of extreme resistance to Potato virus $Y$ controlled by $R y_{\text {sto }}$ of Solanum stoloniferum derived from different sources. Ann Appl Biol 152:121-130

Witek K, Strzelczyk-Żyta D, Hennig J, Marczewski W (2006) A multiplex PCR approach to simultaneously genotype potato towards the resistance alleles $R y-f_{\text {sto }}$ and $N s$. Mol Breed 18:273-275 